\author{
Rafał Rouba \\ Uniwersytet Łódzki \\ Filia w Tomaszowie Mazowieckim \\ 97-200 Toaszów Mazowiecki \\ ul. Konstytucji 3 Maja nr 65/67 \\ rafraf@yahoo.com
}

\section{DYWERSYFIKACJA OCZEKIWAŃ TURYSTÓW, MANAGERÓW I EKSPERTÓW WOBEC DZIEDZICTWA WYKORZYSTYWANEGO W POLSKIEJ TURYSTYCE}

\section{VARIATIONS IN TOURIST, MANAGER AND TOURISM EXPERT EXPECTATIONS OF HOTEL SERVICE IN POLISH HISTORICAL RESIDENCES}

W Polsce funkcjonuje niemal 400 obiektów noclegowych zlokalizowanych w zabytkowych budynkach pałaców, dworów i zamków. Rewitalizacja historycznych rezydencji poprzez funkcję hotelarską określona może zostać jako właściwa, ponieWaż generując dochód niezbędny do trwania obiektu stanowi w pewnym sensie naturalną kontynuację gościnności domów szlacheckich, w których zawsze czekaly pokoje gotowe na przyjęcie podróżnych.

Współczesne hotelarstwo w zabytkowych rezydencjach to unikatowa kombinacja usługi noclegowej i turystyki krajoznawczej zapewniająca nie tylko bezpieczne miejsce, wygodne łóżko, smaczny posiłek, ale także kontakt $\mathrm{z}$ historią - doświadczenie niezwykłe, nieprzeciętne; ponadczasowe obcowanie $z$ dziejami i kulturą narodu w różnych jej przejawach.

Hotelarstwo w obiektach historycznych wyrasta z gruntu turystyki kulturowej opierającej się na walorach materialnych i niematerialnych. Ten rodzaj turystyki został określony przez GOLEMBSKIEGO (2002, s. 340) jako: „aktywność osób w ich miejscach pobytu turystycznego oraz podczas podróży z miejsca stałego zamieszkania, która pozwala na poznanie lub doświadczenie różnych sposobów życia innych ludzi [ludzi w innych czaSach - aut.] - sposobów odzwierciedlających oby-
In Poland there are nearly 400 hotels located in historical palaces, manors and castles. The revitalization of historical residences through a change in function to that of hotel might be described as appropriate, because generating the finance necessary to preserve the buildings becomes in a sense a natural continuation of the traditional hospitality of the houses of the nobility where travellers could always stay for the night.

Contemporary hotel service in historical buildings is a unique combination of hotel service and tourism, providing not only a safe place to stay, a comfortable bed and tasty meals, but also contact with history an exceptional opportunity to experience different aspects of national history and culture.

Hotel service through historical buildings is based on cultural tourism with its material and non-material assets. This type of tourism activity was defined by GOEEMBSKI (2002, p. 340) as: “... places where tourists stay, and during their journey from place of permanent residence, allowing them to learn about or experience the different way of life of others [from the past author's comment] - ways which reflect social customs, religious traditions, ways of 
czaje społeczne, tradycje religijne, myśl intelektualną, dziedzictwo kulturowe i mających na celu zaspokojenie ludzkich potrzeb, pragnień i oczekiwań w zakresie kultury". Z kolei FYALL i GARROD (1998, s. 214) definiują turystykę kulturową jako swego rodzaju działalność ekonomiczna, która za pośrednictwem dziedzictwa kulturowego stara się wykreować popyt turystyczny. ZEPPAL i HALL (1991, s. 49) określają turystykę kulturową jako „opartą na tęsknocie za minionym i powodowana pożądaniem doświadczenia zróżnicowanych przejawów kultury", a PORIA, BUTLER i AIREY (2001, s. 1049) z kolei twierdza, że to „fenomen oparty bardziej na motywacji i percepcji odwiedzających, niż na atrybutach atrakcji jako takiej".

Polski termin ,turystyka kulturowa" wydaje się zdecydowanie zbyt szeroki w odniesieniu do rezydencji pelniących funkcję hotelarską. Dużo bardziej odpowiedni bylby tu angielski heritage tourism, wszakże nie tożsamy z terminem ,turystyka kulturowa”. Heritage tourism ma znacznie węższy zakres bazujący na dziedzictwie kulturowym, czyli dobrach otrzymanych niejako w spadku po przodkach. Jednocześnie wyklucza on całą jakże bogata sferę kultury współczesnej i zjawisk z nią związanych. Ciekawe dywagacje dotyczące tej tematyki prowadzi MAJEWSKI (2002, s. 25), który polemizując z Collinsem (1983), Weiler, Hall (1992), TAssel, TAssel (1990) i Prentice (1993) dowodzi, że jako źródło atrakcyjności heritage tourism (przetłumaczonej przez autora jako turystyka związana $\mathrm{z}$ dziedzictwem kulturowym), prócz budowli historycznych, należy traktować także przeszłe wzory życia codziennego, praktyki religijne, zwyczaje, folklor oraz walory przyrodnicze tworzone ręką ludzką (parki i ogrody). Debata nad terminem heritage tourism została skonkludowana stwierdzeniem, iż jest to poszukiwanie pomostu pomiędzy przeszłością a teraźniejszością powodowane tęsknotą za minionym, przodkami i ojcowizną.

Obdarzanie gości niezapomnianymi doświadczeniami i umożliwianie im kontaktu $\mathrm{z}$ wysublimowanym pięknem zabytkowych budynków pozostaje jedną $\mathrm{z}$ największych zalet hotelarstwa historycznego i jego najbardziej wysmakowanego rodzaju - gościny w pałacach, dworach i zamkach.

Sukces rynkowy przedsięwzięć komercyjnych zależy od znajomości oczekiwań i preferencji klientów, umiejętności ich trafnej identyfikacji, a następnie zaspokojenia. Wszystkie działania promocyjne w przypadku badanych obiektów powin- thinking, the cultural heritage, and which satisfy human needs, wishes and expectations as regards culture." FYALL \& GARROD (1998, p. 214) define cultural tourism as a particular kind of economic activity which tries to generate tourist demand through cultural heritage. ZEPPAL \& HALL (2001, p. 49) describe cultural tourism as "based on the longing for the past and generated by the desire to experience various manifestations of culture", while PORIA, BUTLER \& AIREY (2001, p. 1049) claim that "it is a phenomenon based on the visitors' motivation and perception rather than the attributes of the attraction as such".

The Polish idea of cultural tourism seems to be stretched too widely when referring to those historical residences that perform a hotel function. Heritage tourism would be a much more appropriate term here although it is not identical in meaning. The range of heritage tourism is much smaller based on cultural heritage i.e. on what was handed down by our ancestors. At the same time it excludes the wider sphere of contemporary culture and all its related phenomena. An interesting discussion of these issues was presented by $\mathrm{MA}$ JEWSKI (2002, p. 25), who disagrees with Collins (1983), WEILER \& HALL (1992), TASsel \& TASSEL (1990) and PREnTiCE (1993) and claims that the attractiveness of heritage tourism lies in historical buildings and the everyday patterns of life, religious practices, customs, folklore and man-made natural assets (parks, gardens) in the past. The debate over the term heritage tourism has concluded that it is a search for a link between the past and the present, caused by a longing for the past, our ancestors and roots.

Giving the guests an unforgettable experience and enabling them to be in contact with the sublime beauty of historical buildings is one of the greatest advantages of historical hotel service in its finest form - hospitality in palaces, manors and castles.

The market success of a commercial enterprise depends on knowledge of guests expectations and preferences, and the ability to identify and satisfy them. All promotional activities should be focused on 
ny koncentrować się głównie na eksponowaniu korzyści z nabycia produktu, a także cech szczególnie pożądanych przez potencjalnych nabywców. Poniżej zaprezentowana została próba odpowiedzi na pytanie o preferencje klientów dotyczące noclegów w zabytkowych rezydencjach. Odpowiedzi zostały zestawione $\mathrm{z}$ opinią managerów i pracowników obiektów oraz ekspertów w celu uzyskania modelu oczekiwań względem palaców, dworów i zamków.

Materiał badawczy został zgromadzony w latach 2001-2003, podczas badań terenowych na potrzeby pracy doktorskiej autora pt. Funkcja hotelarska palaców, dworów $i$ zamków w Polsce $i$ jej wplyw na otoczenie. Badanie miało charakter zamknięty - uczestnicy otrzymywali zestawy 14 cech. Zadanie polegało na uszeregowaniu cech od 1 - najważniejszej, do 14 - najmniej ważnej. Badanie oczekiwań gości zostało przeprowadzone na grupie 58 osób - wylosowanych klientów zabytkowych rezydencji, a materiał dotyczący opinii managerów i pracowników pochodzi z wybranej losowo próby, obejmującej 60 z 250 objętych badaniami obiektów. Opinie ekspertów autor zebrał w trakcie prezentacji założeń swojej pracy doktorskiej na spotkaniu gremium Katedry Geografii Miast i Turyzmu Uniwersytetu Łódzkiego. W badaniu udział wzięlo 18 osób, które można bez cienia wątpliwości uznać za ekspertów w dziedzinie turystyki.

Przy opracowaniu i prezentacji wyników autor posłużył się panelem Delfickim, który w zamyśle pierwotnym służy do oceny jakości produktów. Metoda została zaczerpnięta z pracy KACZMARKA, STASIAKA i WŁODARCZYKA (2002 s. 127-134). Prezentacja wyników odbywa się na zmodyfikowanym układzie współrzędnych, gdzie na osiach poziomej i pionowej zaznaczane są otrzymane wyniki istotności danej cechy dla dwóch badanych grup. Koncentracja cech wzdłuż przekątnej układu oznacza zbieżne wyobrażenia badanych grup, duże rozproszenie wskazuje na istotne różnice w postrzeganiu badanych cech.

Istotnych informacji dostarcza położenie cechy w określonym kwadracie i tak:

K-1 zawiera cechy ze wszech miar pożądane, które zostały wysoko ocenione przez obydwie badane próby. Rozwijanie tych cech powinno zostać uznane za priorytetowe, podobnie jak wyraźna ich ekspozycja we wszystkich działaniach promocyjnych.

K-2, K-3 zawierają cechy ocenione wysoko przez jedną grupę, a nisko przez drugą. Umiejsco- presenting the benefits of buying a product and on the features particularly desired by potential buyers. Below the author presents an attempt to answer the question about guests' preferences as regards accommodation in historical residences. The answers were compared with opinions expressed by managers of these hotels, as well as by tourism experts, in order to obtain a generalised model of expectations concerning palaces, manors and palaces.

The study material was collected in $2001 / 3$ during fieldwork done by the author for his doctoral thesis entitled The Hotel Function of Palaces, Manors and Castles in Poland and its effect on Surrounding Areas. The research was set up in advance and the respondents received a specified set of 14 features. They were supposed to put them in order from 1 - the most important to 14 - the least. The research was carried out with a group of 58 randomly selected guests of historical residences, and the material on managers' opinions comes from a randomly selected sample of 60 out of 250 heritage hotels. Tourism expert opinions were collected during the presentation of the author's doctoral thesis in front of representatives of the Department of Urban and Tourism Studies, University of Łódż. Eighteen, who can indisputably be regarded as experts on tourism, were approached.

While interpreting and presenting the results, the author used the 'Delphic panel', which was originally used for evaluating the features of a specific good. The method was borrowed from the work by KACZMAREK, STASIAK \& WKODARCZYK (2002 pp. 127-134). The results are presented on a modified coordinate plane where on the horizontal and vertical axes the positions of given features are marked for the two groups under study. A concentration of features along the diagonal line signifies a similar perception between the groups, while wide dispersion to significant differences.

The location of a feature in a quadrant provides important information:

K-1 contains strongly desired features which have been highly evaluated by both groups. Developing these features and 
wienie w kwadratach K-2 i K-3 dowodzi zdecydowanej rozbieżności w opinii na temat danych cech pałaców, dworów i zamków pełniących funkcję hotelarską. O ile rozbieżność między opinią ekspertów i turystów lub managerów ma charakter czysto informacyjny, o tyle niekoherencja na linii managerowie-goście powinna skutkować wnikliwą analizą otrzymanego wyniku i opracowaniem programu korygującego. their strong exposure in all promotional activities should be priorities.

$\mathrm{K}-2$ and $\mathrm{K}-3$ contain features which have been evaluated highly by one group but lower by the others. This location reflects a clear divergence of opinion regarding the palaces, manors and castles which provide hotel services. While the differences between tourism experts on one side, and guests and managers on the other are simply a statement of fact, the mismatching of opinion between managers and tourists should result in a thorough analysis and suggestions for a programme of marketing improvements.
Rys. 1. Opinia gości, ekspertów i managerów na temat pożąanych cech pałaców, dworów i zamków pełniących funkcję hotelarską w latach 2001-2003 (żródło: opracowanie własne na podstawie badań)

A - atrakcje dodatkowe związane $z$ historycznym charakterem obiektu, B - atrakcyjne usytuowanie, C - cisza i spokój, D - do bry dojazd, E - funkcjonalność $F$ - gościnność, G - historia obiektu, $\mathrm{H}$ - niepowtarzalność 1 - nowoczesne wyposażenie $\mathrm{J}$ - piękno budynku, $\mathrm{K}$ - przy stępne ceny, $L$ - wysoki standard, $M$ - zabytkowy wystrój pokoi, $\mathrm{N}$ - znajomość języków obcych

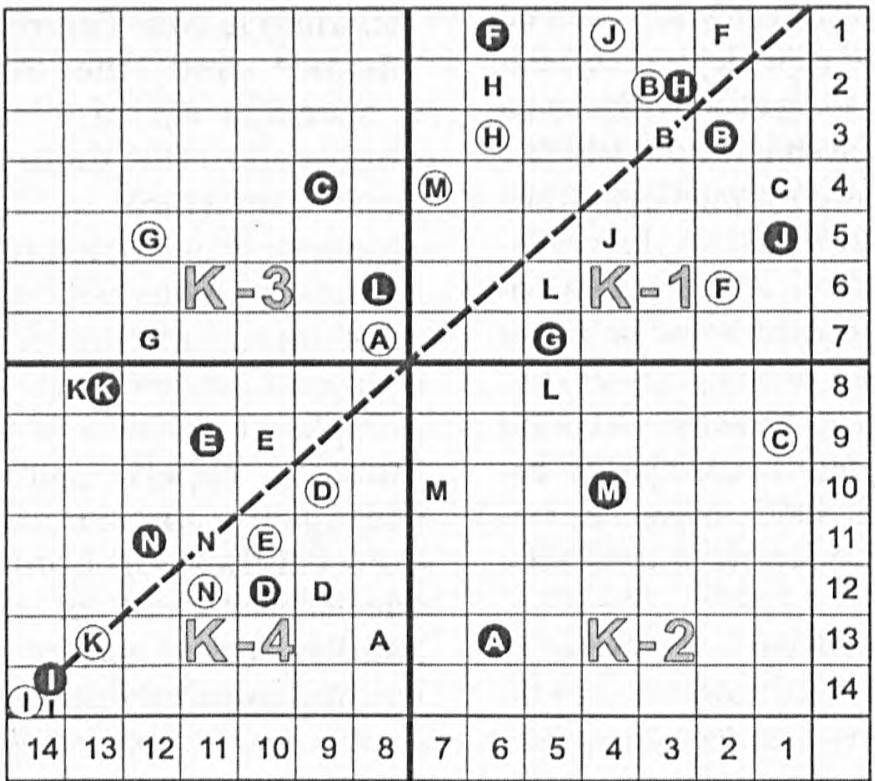

(A) A GOŚCIE / GUESTS A EKSPERCI / EXPERTS
() Fig. 1. The opinions of guests, tourism experts and managers regarding desirable features of palaces, manors and castles that perform a hotel function (in 2001-3) (s o u r c e: authorbased on survey)

A - additional attractions due to the historical character of the building, B - attractive location, C - peace and quiet, D - convenient access, $E$ - functionality, F-hospitality, A $\mathrm{G}$ - history of the building, $\mathrm{H}$ - uniqueness, 1 - modern equipment/facilities, $\mathrm{J}$ - beauty of the building, $\mathrm{K}$ - affordable prices, L - high standards, $M$ - historical furnishing, $\mathrm{N}$ - knowledge of foreign languages
K-4 zawiera cechy określone jednogłośnie przez badane grupy jako nieistotne. Umieszczenie w kwadracie K-4 sygnalizuje niewielką obiektywną wagę danej cechy, co przekładać się może na zaprzestanie eksponowania jej w działaniach marketingowych.

Przeprowadzone badanie dało bardzo ciekawe wyniki, które mogą zostać wykorzystane w praktyce podczas układania planu marketingowego i strategii promocji zabytkowych rezydencji pelniących funkcję hotelarską. Analiza rozproszenia badanych cech na układzie współrzędnych wykazała, że najmniej zgodne są opinie managerów i ekspertów (największe rozproszenie cech względem ,linii zbieżnych poglądów"), a poglądy gości i ekspertów oraz managerów i gości cechuje umiarkowana zbieżność.
K-4 contains features described as unimportant by both groups. Location in this quadrant means a low level significance for a given feature allowing it to be eliminated from marketing activities.

The survey brought in very interesting results which can be used in practice for the preparation of a marketing plan and a strategy for promoting such historical residences. The analysis of features shows that managers and tourism experts disagree the most (the strongest dispersion of features around a line of similar opinions), while the opinions of guests and tourism experts and managers are relatively similar. 


\section{MANAGEROWIE VS. GOŚCIE}

Jako pierwsze zostanie omówione najważniejsze $\mathrm{z}$ rynkowego punktu widzenia porównanie opinii managerów i gości dotyczących istotności poszczególnych cech pałaców, dworów i zamków pełniących funkcję hotelarska.

Obecność sześciu cech w kwadracie K-1 oznacza, iż są one uważane zarówno przez gości, jak i przez managerów jako decydujące o udanym pobycie. Wysoka pozycja w opinii gości oznacza, że są to cechy oczekiwane, pożądane, których spelnienie pozwala zaliczyć pobyt do pozytywnych doświadczeń. Podobnie wysoka pozycja w deklaracjach managerów wskazuje, że mając świadomość wagi tych czynników dokładają oni wszelkich starań, aby zostały zapewnione.

Cechą o największym znaczeniu dla obu grup była gościnność $(1,2)$, przy czym dla managerów była o punkt ważniejsza niż dla gości, którzy pierwszą pozycję przyznali ciszy i spokojowi $(4,1)$. Duża zbieżność opinii występuje w zakresie atrakcyjnego usytuowania $(3,3)$, jak również piękna budynku $(5,4)$ oraz wysokiego standardu $(6,5)$. Niepowtarzalność zaliczono do grona cech najistotniejszych, jednak $\mathrm{z}$ największą rozbieżnością zdań $(2,6)$, przy czym, o dziwo, niepowtarzalność została znacznie wyżej oceniona przez managerów.

W kwadratach K-2 i K-3, zawierających cechy ocenione przez grupy respondentów diametralnie różnie, znalazly się tylko dwa punkty. Zabytkowy wystrój pokoi $(10,7)$ wydaje się managerom nieistotny, podczas gdy goście przywiązują do niego zdecydowanie większą wagę. Zaskakująca jest pozycja historii obiektu $(7,12)$, która przez managerów oceniona wyżej, dla klientów okazała się nie mieć większego znaczenia.

Kwadrat K-4 zawiera ostatnie sześć cech, które zarówno przez gości, jak i managerów uznane zostały za najmniej istotne. Ostatnie miejsce, identycznie dla obydwu grup, zajęło nowoczesne wyposażenie obiektu $(14,14)$. Zaskakiwać może niska pozycja obsługi mówiącej w językach obcych $(11,11)$ - tak niską pozycję wyjaśnić można małym związkiem obsługi mówiącej w językach obcych ze specyfiką obiektu. Pośród cech mniej istotnych znalazła się również funkcjonalność $(9,10)$, co może oznaczać, że zarówno jedni, jak i drudzy są w stanie zaakceptować pewne niedogodności wynagradzane pięknem bu-

\section{MANAGERS VS GUESTS}

First a comparison of the opinions of managers and guests regarding the significance of those individual features of palaces, manors and castles regarded as the most important from a marketing perspective.

The presence of six features in quadrant $\mathrm{K}-1$ means that they are considered to be the determinants of a satisfying stay by both guests and managers. The guests' positive opinion means that they are features which are expected and desired, guaranteeing the stay to be a positive experience. Similarly, such an opinion expressed by managers means that, aware of how important these particular features are, they do their best to provide them.

The most important feature for both groups was hospitality (position 1 managers, position 2 - guests), managers evaluating it slightly higher than guests who gave priority to peace and quiet $(4,1)$. The opinions strongly converge as regards attractive location $(3,3)$, the beauty of the building $(5,4)$ and high standards $(6,5)$. Uniqueness is one of the most significant features, but with the strongest divergence of opinions $(2,6)$; surprisingly, it was evaluated much more highly by managers.

Quadrants $\mathrm{K}-2$ and $\mathrm{K}-3$ contain the features evaluated completely differently. There are only two: historical furnishings $(10,7)$ seem insignificant to managers while guests consider them to be quite important while the positions given to the history of the building $(7,12)$ are surprising, as it turns out to be more important to managers than guests.

Guadrant $\mathrm{K}-4$ includes the remaining six features which were considered to be the least important both by managers and guests. For both groups modern facilities in the building $(14,14)$ were least important. The low position of staff knowledge of foreign languages $(11,11)$ may be surprising; such a low position could be explained by the weak correlation between the staff and the special character of the building. The group of less important features also includes functionality $(9,10)$ which may mean that both groups are ready to accept certain inconveniences compensated for by 
dynku czy atrakcyjnym usytuowaniem. Duża rozbieżność w opiniach występuje w przypadku przystępnej ceny $(8,13)$. Co ciekawe - to managerowie uznaja ja za ważniejsza, podczas gdy goście, umieściwszy ją na przedostatniej pozycji, wykazali skłonność do płacenia wyższych rachunków za pobyt w rezydencjach historycznych. Najmniejsze znaczenie managerowie przywiazuja do atrakcji związanych $\mathrm{z}$ historycznym charakterem obiektu $(13,8)$ i dobrego dojazdu $(12,9)$, natomiast goście obydwie cechy zaklasyfikowali wyżej.

\section{EKSPERCI VS. MANAGEROWIE}

Konfrontacja opinii managerów z poglądami ekspertów wydaje się być istotna $\mathrm{z}$ kilku powodów: eksperci nie tylko, że prezentują punkt widzenia najwyższej klasy specjalistów od zagadnień turystyki, ale dodatkowo można ich jeszcze uznać za ewentualnych reprezentantów najlepiej wykształconego, a co się z tym wiąże, świadomego i wymagającego segmentu rynku konsumenckiego.

Opinie managerów i ekspertów są zdecydowanie mniej zbieżne, niż managerów i gości.

W kwadracie K-1 znalazlo się pięć czynników. Eksperci wespól z managerami korzystniej od gości ocenili piękno budynku $(5,1)$, stawiając je zdecydowanie na pierwszym miejscu, na następnych umieszczając niepowtarzalność $(2,3)$ i atrakcyjne usytuowanie $(3,2)$. Niższą pozycję aniżeli poprzednio uzyskała gościnność $(1,6)$, nie będąca zdaniem ekspertów najważniejszym elementem W obiekcie zabytkowym. W kwadracie K-1 pojawiła się historia obiektu doceniona jedynie przez ekspertów (7, 5). Eksperci nie uznali za szczególną wartość ciszy i spokoju, która zniknęła z kwadratu K-1.

Kwadraty K-2 i K-3 mieszczą po dwie cechy mające zdecydowanie rozbieżną notę ekspertów i managerów. Wysoką ocenę ekspertów (przy braku zainteresowania managerów) zaobserwować można w stosunku do zabytkowego wystroju pokoi $(10,4)$ i atrakcji zwiazzanych z zabytkowym charakterem obiektu $(13,6)$. Sytuacja odwrotna - istotność z punktu widzenia managerów, przy mniejszej wadze przywiązanej przez ekspertów, zauważyć można w przypadku wysokiego standardu $(6,8)$ oraz ciszy i spokoju $(4,9)$. the beauty of the building or its attractive location. A strong divergence of opinion is observed as regards affordable prices $(8,13)$. What is interesting here is that it is the managers who consider it more important, while guests placed it second to last showing their readiness to pay more for stays in historical residences. The other features evaluated lowest by managers are attractiveness resulting from the historical character of the building $(13,8)$ and convenient access $(12,9)$, while guests evaluated both these features more highly.

\section{MANAGERS VS TOURISM EXPERTS}

Contrasting managers' and tourism experts' opinions seems important for several reasons; the tourism experts not only present the point of view of the highest quality tourism specialists, but they can also be regarded as possible represent-atives of the best educated, most conscious and demanding part of the consumer market.

The opinions of managers and tourism experts are clearly less convergent than those of managers and guests.

Quadrant K-1 contains five features. Tourism experts evaluated the beauty of the building (position 5 - managers, position 1 tourism experts) more highly than guests placing it first. This was followed by attractive location $(3,2)$ and uniqueness $(2$, 3). Hospitality was evaluated lower than for guests $(1,6)$; tourism experts believing that it is not the most important element in a historical building. Quadrant K-1 also included the history of a building, appreciated highly only by tourism experts $(7,5)$, who at the same time did not consider peace and quiet to be particularly important and it disappeared from the quadrant.

Quadrants K-2 and K-3 contain two features each, which are evaluated very differently by tourism experts and managers. The tourism experts highly evaluated and the managers ignored the importance of the historical furnishings $(10$, 4) and the attraction of the historical character of the building $(13,6)$. The opposite situation was found regarding high standards $(6,8)$ and peace and quiet $(4,9)$, 
Kwadrat K-4, wskazujący na czynniki umieszczone na końcu listy przez obie grupy respondentów, zawiera pięć pozycji: nowoczesne wyposażenie $(14,14)$ i znajomość języków obcych przez obsługe $(11,12)$, przystępne ceny $(8,13)$ i dobry dojazd $(12,10)$ utrzymały niezmiennie niskie pozycje, bardzo zbliżone do poprzedniego rozkladu. Jedynie atrakcje dodatkowe związane $\mathrm{z}$ charakterem obiektu, znalazłszy wyższe uznanie w oczach ekspertów trafily do kwadratu $\mathrm{K}-2$.

\section{GOŚCIE VS. EKSPERCI}

Przeciwstawienie sobie opinii gości i ekspertów dało bardzo ciekawy wynik, ponieważ $\mathrm{w}$ istocie oba punkty widzenia należą do konsumentów, przy czym jeden $\mathrm{z}$ nich charakteryzuje odbiorce przeciętnego, podchodzącego do odwiedzanego obiektu niekiedy bez refleksji, natomiast drugi reprezentacje ludzi światlych, wykształconych i przyzwyczajonych do codziennej refleksji nad rzeczywistością. Zderzenie tych dwóch poglądów pokazało że:

W kwadracie K-1 znalazło się ponownie pięć czynników, z czego cztery: piękno budynku $(1,4)$, atrakcyjne usytuowanie $(2,3)$, niepowtarzalność $(3,6)$ i gościnność $(6,3)$, pojawiały się już w tym kwadracie wcześniej, podczas gdy zabytkowy wystrój pokoi $(4,7)$, zdecydowanie nie doceniany przez managerów, został uznany za ważny zarówno przez gości, jak i ekspertów.

W kwadratach K-2 i K-3 znaleźć można ciszę i spokój $(9,1)$ oraz wysoki standard $(8,5)$, uznane przez ekspertów za mało istotne, za to docenione przez gości. Odwrotna sytuacja miala miejsce w przypadku historii obiektu $(5,12)$ - zdecydowanie zignorowanej przez gości - i atrakcji historycznych związanych $\mathrm{z}$ charakterem obiektu $(7,8)$.

W kwadracie K-4 nie zaobserwowano większych zmian. Nowoczesne wyposażenie $(14,14)$ i znajomość języków obcych $(12,11)$ pozostają niezmiennie na końcu stawki. Dołączyly do nich przystępne ceny, jako że obie grupy, zarówno eksperci, jak i goście, w odróżnieniu od managerów, wychodzą $\mathrm{z}$ założenia, że cena za pobyt w zabytkowej rezydencji nie musi być niska. Funkcjonalność $(11,10)$ i dobry dojazd $(10,9)$ również niewiele się różnią $\mathrm{w}$ stosunku do pozycji, które osiąnęly we wcześniejszych badaniach. which were appreciated by managers and disregarded by tourism experts.

Guadrant K-4 presents the five features placed at the end of the ranking list by both groups: modern facilities $(14,14)$, staff knowledge of foreign languages $(11,12)$, affordable prices $(8,13)$ and convenient access $(12,10)$. Only the additional attractions coming from the character of the building were appreciated more highly by tourism experts and appeared in quadrant $\mathrm{K}-2$.

\section{TOURISM EXPERTS VS GUESTS}

Contrasting guests' and tourism experts' opinions brought a very interesting result because in fact both are from a consumer perspective. The first represents average consumers who sometimes do not reflect on the building they visit, and the second represents the highly-educated who are used to daily reflection on reality. Contrasting these two viewpoints showed the following results:

Quadrant K-1 included five features, four of which - the beauty of the building (position 1 - tourism experts, position 4 guests), attractive location $(2,3)$, uniqueness $(3,6)$ and hospitality $(6,3)$ had appeared in this quadrant before. The fifth, i.e. historical furnishings $(4,7)$, clearly given less value by managers, was considered important by both guests and tourism experts.

Guadrant $\mathrm{K}-2$ and $\mathrm{K}-3$ included peace and quiet $(9,1)$ and high standards $(8,5)$, both considered by tourism experts to be of little importance, but appreciated by guests. An opposite situation occurred regarding the history of the building $(5,12)$ - clearly valued little by guests, along with the historical attractions from the character of the building $(7,8)$.

In quadrant $\mathrm{K}-4$ significant differences were not observed. Modern facilities $(14,14)$ and staff knowledge of foreign languages $(12,11)$ still remain at the end of the ranking list. They were joined by affordable prices, because both groups in contrast to managers believe that the price for a stay in such residence does not have to be low. The position of functionality $(11,10)$ and convenient access is not much different either. 


\section{PODSUMOWANIE}

Podsumowując rozważania na temat pożądanych cech pałaców, dworów i zamków pelniących funkcję hotelarską można zauważyć, że najwięcej cech niematerialnych $(50 \%)$ występuje w elementach zdecydowanie pożądanych, co podkreśla ich wagę przy promocji produktu rezydencji. Przez wszystkie grupy respondentów wymieniane jako najkorzystniejsze były: piękno budynku, gościnność, niepowtarzalność, atrakcyjne usytuowanie. Jako najmniej ważne zgodnie wymieniano: funkcjonalność, dobry dojazd, nowoczesne wyposażenie, przystępne ceny, znajomość języków obcych przez obsługę. Do cech przez jedne grupy uznanych za pożądane i ważne, a dla innych mniej istotne należy: cisza i spokój, historia obiektu, wysoki standard, zabytkowy wystrój pokoi. Cechą w każdym wypadku dyskusyjną byly atrakcje związane $\mathrm{z}$ historycznym charakterem obiektu.

Na podstawie powyższych rozważań stwierdzić można, że modelowa rezydencja historyczna pelniąca funkcję hotelarską to pięknem wynagradzający drobną niefunkcjonalność budynek zlokalizowany w atrakcyjnym otoczeniu. Niepowtarzalność całości łagodzi niedogodności będące wynikiem skomplikowanego dojazdu, a gościnność - ceny, które nie muszą być niskie. Nowoczesne wyposażenie i mówiąca w językach obcych obsługa są zupelnie zbędne, podczas gdy cisza i spokój powinny występować okresowo, podobnie jak historia obiektu, która tylko czasem dodaje uroku. Część pokoi w obiekcie powinna reprezentować wysoki standard i być umeblowana zgodnie $\mathrm{z}$ charakterem obiektu. Atrakcje związane z historycznym profilem obiektu są kwestia zdecydowanie najbardziej dyskusyjna.

\section{CONCLUSIONS}

Concluding the discussion of the desired features of palaces, manors and castles performing a hotel function, we observe that a majority of non-material features (50\%) are found among the most strongly desired elements, which should increase their importance during the promotion of a given residence. All groups of respondents gave the beauty of the building, hospitality, uniqueness and attractive location as the most important. Functionality, convenient access, modern facilities, affordable prices, and staff knowledge of foreign languages were considered by all groups as the least significant features. Among features regarded as desirable and important by only one or two of the groups are: peace and quiet, the history of the building, high standards and historical furnishings. An undecided point was the position allocated to the attractiveness of the historical character of the building.

In can be concluded that a generalised model for such a historical residence is an attractively located building, whose beauty compensates for its slightly impaired functionality. Its uniqueness makes the inconvenient access feel less troublesome, and the hospitality makes up for the prices which do not have to be low. Modern facilities and the staff speaking in foreign languages are considered less significant, while peace and quiet ought to be available, likewise the history of the building though it only occasionally adds to its attractiveness. At least some of the rooms should be of a high standard and furnished in accordance with the character of the building. The status of the attractions connected with the historical profile of the building is the most undecided issue.

\section{BIBLIOGRAFIA - BIBLIOGRAPHY}

Coluins R., 1983, Tourism and Heritage Conservation: The Pacific Experience, Heritage Australia.

Fyall A., GARROD B., 1998, Heritage tourism: At what price?, Managing Leisure, 3.

GolEMBSKI G. (red.), 2002, Kompendium wiedzy o turystyce, Wyd. Naukowe PWN, Warszawa-Poznań.

Kaczmarek J., Stasiak A., Wlodarczyk B., 2002, Produkt turystyczny, Wyd. Uniwersytetu Łódzkiego, Łódź.

MAJEWSKI J., 2002, Interpretacja dziedzictwa kulturowego w turystyce wiejskiej, Problemy Turystyki i Hotelarstwa, 4.
Prentice M., 1993, Tourism and Heritage Attractions, Routlege, London.

PORIA, Y., BUTLER, R., AIREY D., 2001, Clarifying heritage tourism, Annals of Tourism Research, 28.

TASSEl C., TASSEL M., 1990, The Tasmanian Rural Landscape, Heritage Australia.

WeIler B., Hall C., 1992, Special Interest Tourism, Bellhaven Press, London.

ZEPPAL H., HALL C., 1991, Selling art and history: Cultural heritage and tourism, Tourism Studies, 2. 